\title{
BENTHIC MACROINVERTEBRATE DIVERSITY AND FUNCTIONAL FEEDING GROUPS IN RELATION TO PHYSICOCHEMICAL FACTORS IN SANJIANG PLAIN WETLANDS, NORTHEAST CHINA
}

\author{
Shabani, I. E. ${ }^{1}-$ LiU, M. H. ${ }^{1 *}-$ YU, H. X. ${ }^{1 *}-$ MuhigWA, J.-B. B. ${ }^{2}-$ GenG, F. F. ${ }^{3}$ \\ ${ }^{1}$ Laboratory of Hydrobiology, College of Wildlife Resource, Northeast Forestry University \\ Harbin P.O. Box 150040, China \\ ${ }^{2}$ Département de Biologie, Faculté des Sciences, Université Officielle de Bukavu \\ P.O. Box 570-Bukavu, République Démocratique du Congo \\ ${ }^{3}$ College of Art, Harbin University of Science and Technology, Harbin P.O. Box 150040, China \\ *Corresponding authors \\ e-mail:manhong@nefu.edu.cn; china.yhx@163.com
}

(Received $18^{\text {th }}$ Dec 2018; accepted $14^{\text {th }}$ Feb 2019)

\begin{abstract}
Sanjiang plain wetland is the largest freshwater ecosystem in northeast China, and with its richness in animal and plant species, it displays a high biodiversity. This study provides information about benthic macroinvertebrate diversity and functional groups in association with physicochemical parameters in wetland habitats of Sanjiang plain. Benthic macroinvertebrate samples were collected using a D-frame aquatic net. Shannon-Wiener, Simpson and Pileou's evenness indices were calculated in terms of abundance. The relationship between measured physicochemical variables and benthic macroinvertebrate functional feeding groups (FFGs) was explored using CCA. A total of 57 macroinvertebrate taxa were collected from the 16 sampling sites. Aquatic insects were the most abundant with 11 families, Dytiscidae, Chironomidae, Leptophlebiidae, Belostomatidae, Corixidae, Gerridae, Corduliidae, Gomphidae, Macromiinae, Libellulidae and Phryganeidae. Chironomids were the most diverse and abundant with 26 taxa. The metrics of abundance, Shannon-Wiener, Simpson and Pileou's evenness indices differed significantly among the 16 sampling sites $(p=0.0163, p=0.0092, p=0.0474$, $p=0.0222$, respectively). The findings showed that these 57 benthic macroinvertebrate taxa were categorized in six functional feeding groups, including 19 predators, 15 gathering-collectors, 7 scrapers, 6 filtering-collectors, 5 omnivores and 5 shredders. CCA results displayed that benthic macroinvertebrate functional feeding groups had strong relationships with the physicochemical characteristics in the wetlands of Sanjiang plain.
\end{abstract}

Keywords: aquatic macroinvertebrate fauna, functional group composition, water parameters, wetland, China

\section{Introduction}

Wetland ecosystems account for 5-8\% of the Earth's surface area (Sui et al., 2017) with their characteristic mix of land and water. They display the richest biodiversity, highest productivity, and highest ecological impact of all terrestrial ecosystems (Sui et al., 2017). They are important for the reduction of greenhouse gas emission, conservation of biodiversity, and contribute to regulating the balance of the Earth's ecosystem (Galloway et al., 2004; Dentener et al., 2006). Aquatic ecosystems are mostly affected by the large-scale agricultural expansion which influences the overall quality of the ecosystems by directly altering habitat, channel structure, and water quality posing severe threats to aquatic biodiversity (Vitousek et al., 1997; Allan, 2004; Azrina et al., 2006; Dudgeon et al., 2006; Smith and Lamp, 2008; Carlson et al., 2013; 
Narangarvuu et al., 2014). Most aquatic macroinvertebrates reside in the benthic biotope for at least part of their life, relatively immobile, and very sensitive; therefore any disturbances in the aquatic environment may cause them to disappear or a reduction in their diversity (Hilsenhoff, 1988; Zamora-Muñoz et al., 1995; Morse et al., 2007; Narangarvuu et al., 2014). Hence, biomonitoring is considered as one of the alternatives for rapid assessment of the aquatic environment status (Tan and Beh, 2016).

Aquatic macroinvertebrates are widely used as biological indicators of the ecological conditions, their abundance and diversity being used to evaluate the occurrence of pollution (Abel, 1966; Hellawell, 1986; Metcafe, 1989; Lenat, 1993; Rosenberg and Resh, 1993; Rosenberg et al., 2008; Southerland et al., 2008; Shabani et al., 2016). While macroinvertebrates in wetlands share some of their attributes in streams and rivers useful such as ubiquity, sedentary nature, moderately long life cycles, environmental sensitivity (Rosenberg and Resh, 1993), they have many other attributes that reduce their ability to reflect environmental quality such as strong responses to weather and seasonality, and frequent dispersal into and out of habitats (Rosenberg et al., 2008).

In standing and flowing water ecosystems, aquatic macroinvertebrates are important elements in the ecological dynamics (Hynes, 1970), playing an important role in the cycle of materials and in trophic transfers (Cummins, 1974; Vannote et al., 1980; Cummins et al., 1989; Dunbar, 2010; Shabani et al., 2016; Safari et al., 2018). They are important animal organisms both economically and ecologically (Li et al., 2007).

Understanding the distribution and abundance of invertebrates in aquatic ecosystem has long been a goal of aquatic ecologists (Bergon, 1996). Immature stages of aquatic invertebrates are a vital link between primary producers and fish (Yapo et al., 2018). Most aquatic macroinvertebrates are sensitive to changes in $\mathrm{pH}$, dissolved oxygen, temperature, salinity, turbidity, conductivity, availability of food and other changes in their biotope (Gage et al., 2004; Crisci-Bispo et al., 2007). They are useful surrogates of ecosystem attributes, and the relative abundance of functional groups reflects anthropogenic impact (Merritt et al., 2002; Cummins et al., 2005; Masese et al., 2014).

Sanjiang plain wetland is the largest freshwater wetland in northeast China (Zheng et al., 2013; Liu et al., 2014; Taufik et al., 2015; Wu et al., 2017), and with its richness in animals and plant species, it displays a high biodiversity. It is world-renowned for hosting many rare, large-sized water birds; several most notable ones are globally threatened cranes, such as the Oriental stork (Ciconia boyciana), white-naped crane (Grus vipio), and red-crowned crane (G. japonensis) (Zhang et al., 2009a). Its role in maintaining the ecological balance in the region is irreplaceable (Zheng et al., 2013; Liu et al., 2014). However, qualitative and quantitative studies of aquatic macroinvertebrates in the area remain generally scarce due to the lack of large-scale investigations and insufficient data. Thus, the conservation status of many benthic macroinvertebrates in the Sanjiang plain wetland is not yet assessed. In order to reach a rational and sustainable management of freshwater wetlands of Sanjiang plain, it is very crucial to implement a follow-up study program, to monitor and classify the freshwater macroinvertebrates (Shabani et al., 2016). The identification of species and their distribution patterns provide more information for monitoring and conserving these important ecosystems (Maneechan and Prommi, 2015). Community indices, diversity indices, and functional feeding groups (FFGs) were the most effective measures that can be used in water quality assessment, and have a response across a range of human influence (Rosenberg and Resh, 1993; Merritt et al., 1996, 2002; Karr and Chu, 1999; 
Masese et al., 2014). FFGs are a classification approach that is based on morphobehavioral mechanisms of food acquisition rather than taxonomic group (Merritt et al., 1996). This study aimed to collect benthic macroinvertebrate fauna, and explore the relationships between macroinvertebrate FFGs and water physicochemical properties in the wetland environments of Sanjiang plain.

\section{Materials and methods}

\section{Study area}

The Sanjiang Plain is located in the northeast boarder part of the Heilongjiang Province in NE China (Zhang et al., 2009a; Fig. 1). It is in a low alluvial plain of Heilong River, Songhua River, and Wusuli River (Zhou and Liu, 2005; Zhang et al., 2009a; Jiang et al., 2011), from $129^{\circ} 11 \mathrm{E}$ to $135^{\circ} 05 \mathrm{E}$ and from $43^{\circ} 49 \mathrm{~N}$ to $48^{\circ} 27 \mathrm{~N}$, covering a total area of 108,900 $\mathrm{km}^{2}$ (Liu and Ma, 2002; Jiang et al., 2011; Du et al., 2018). The Sanjiang plain supports one of the largest freshwater wetland complexes in China, and its wetland areas are strongly affected by agriculture drainage and reclamation efforts (Wu et al., 2017). Its elevation in the southwest is higher than in the northeast. The climate in this area belongs to the temperate humid or sub-humid continental monsoon climate. The mean annual temperature ranges from $1.4-4.3{ }^{\circ} \mathrm{C}(\mathrm{Du}$ et al., 2018), with average maximum of $21-22^{\circ} \mathrm{C}$ in July and average minimum $-18{ }^{\circ} \mathrm{C}$ in January (Wang et al., 2015). The mean annual precipitation is $500-650 \mathrm{~mm}$ and $80 \%$ of rainfall occurs between May and September (Jin et al., 2015). The frost-free period is 120-140 days (Yang et al., 2018). Most of the rivers in the area have the characteristics of the wetland river: the slight gradient and large channel curve coefficient. There are four main soil types: meadow soil, swamp soil, washed and black soil. They account for more than $95 \%$ of the whole area. Main types of vegetation in Sanjiang plain include Phragmites communis, Carex lasiacarpa, Carex pseudocuraica, Carex meyeriana, Alnus sibirica, Betula fruticosa, Salix brachypoda, Lythrum salicaria, Calamagrostis anagustifolia (Wang et al., 2018), and the Sanjiang plain wetland has been designated within list of wetlands of international importance (Zhang et al., 2009). Due to the relatively cold weather, deep surface waters, large marsh patches, and sparse population, reclamation of small Sanjiang plain marshes started relatively late, and the Honghe National Nature Reserve and Sanjiang National Nature Reserve were created (Zhang et al., 2009; Du et al., 2018).

\section{Benthic macroinvertebrate procedures}

Sixteen sampling sites were selected based on prospected freshwater ecosystems and accessibility (catchment areas including sites 1, 2, 3, 4, 5 and 6; ponds: sites 7 and 15; marshes: site 8; rivers: sites 9,11,12, 13 and 16; lake: site 10; ditches: site 14). The latitude and longitude of the 16 sampling sites were determined using a portable global positioning system (GPS, Table 1). Benthic macroinvertebrates were collected using a D-frame aquatic net $(30 \times 30 \mathrm{~cm}$ frame, $500 \mu \mathrm{m}$ mesh $)$ and the sampling gears were washed thoroughly between sites during three seasons: autumn, spring and summer of year 2016. In each sampling period, 3 replicate samples were collected at each site and the sampled specimens were sieved through a $500 \mu \mathrm{m}$ mesh sieve in the field for approximately 30-40 min. Macroinvertebrate populations were separated from the sand, mud and substrates by hand. The specimens were grouped according to the sites and 
dates of sampling and placed in $100 \mathrm{ml}$ labelled plastic containers, preserved in $95 \%$ ethanol, and then transported to the laboratory for further analysis.

In the laboratory, the macroinvertebrate communities were keyed to species or genus and counted using identification keys of Thorp and Covich (1991); Morse et al. (1994); Merritt et al. (1996); Tong (1996); Dudgeon (1999); Duan et al. (2010).

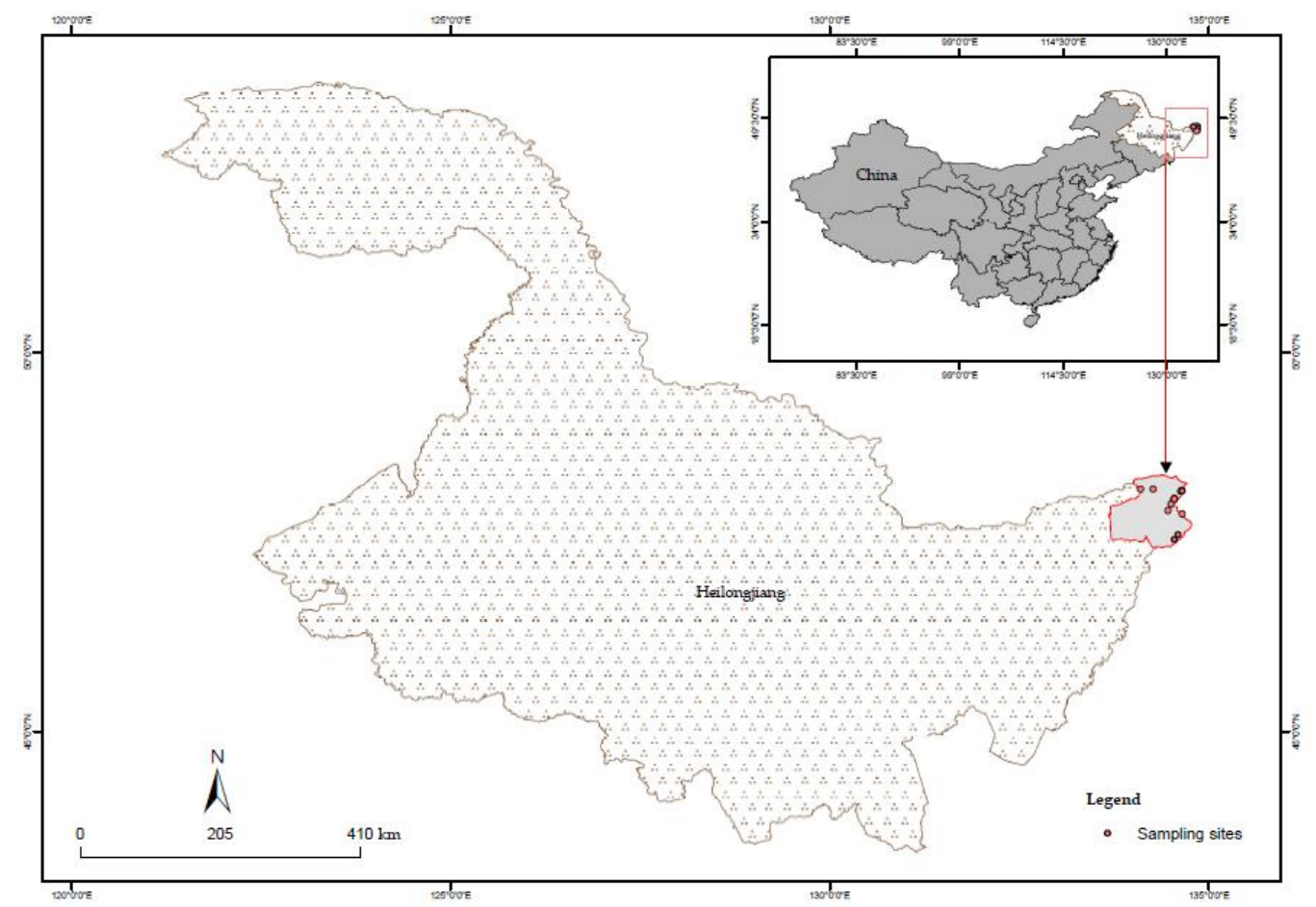

Figure 1. The location of study area with sampling sites within China

\section{Functional group composition}

Major functional feeding groups were assigned based on invertebrate morphological and behavioral adaptations for food acquisition (Merritt et al., 2002; Merritt et al., 1996) and 6 FFGs (shredders, scrapers, filtering-collectors, gathering-collectors, predators and Omnivores) that were identified. The FFGs are: 1) shredders (SH) feeding on coarse particulate organic matter $>1 \mathrm{~mm}$ in size, either live aquatic macrophyte tissue or coarse terrestrial plant litter; 2) scrapers (SC) scraping off and consuming the organic matter attached to stones and other substrate surfaces, primarily live plant stems; 3) filteringcollectors (FC) sifting fine particulates 1000 to $0.45 \mu \mathrm{m}$ from the flowing column of water; 4) gathering-collectors (GC) which gather fine particulates of organic matter from the debris and sediments on the stream beds; 5) predators (PR) feeding on other animals, i.e. live prey; and a sixth category, other, includes species that are omnivores $(\mathrm{OM})$, or simply do not fit neatly into the other categories (Zhang et al., 2014; Masese et al., 2014; Fu et al., 2016).

\section{Measurement of physicochemical factors}

Simultaneously with benthic macroinvertebrate sampling, the water temperature $\left(\mathrm{T}^{\circ} \mathrm{C}\right)$, electrical conductivity $(\mathrm{EC}, \mu \mathrm{S} / \mathrm{cm}), \mathrm{pH}$, chlorine $\left(\mathrm{Cl}^{-}, \mathrm{mg} / \mathrm{l}\right)$, turbidity (NTU), 
chlorophyll a (Chl, mg/l) were measured using multi-parameter probe YSI Professional (YSI 06E2512AG). The transparency $(\mathrm{cm})$ was measured with a Secchi disc. Water samples were collected from each sampling site in $500 \mathrm{ml}$ labelled plastic containers. Chemical parameters such as chemical oxygen demand $\left(\mathrm{COD}_{\mathrm{Mn}}, \mathrm{mg} / \mathrm{l}\right)$, biological oxygen demand $\left(\mathrm{BOD}_{5}, \mathrm{mg} / \mathrm{l}\right)$, total nitrogen $(\mathrm{TN}, \mathrm{mg} / \mathrm{l})$, ammonia-nitrogen $\left(\mathrm{NH}_{3}-\mathrm{N}\right.$, $\mathrm{mg} / \mathrm{l})$, nitrate $\left(\mathrm{NO}_{3}{ }^{-}, \mathrm{mg} / \mathrm{l}\right)$, and total phosphorus $(\mathrm{TP}, \mathrm{mg} / \mathrm{l})$ were analyzed in the laboratory based on standard methods procedures (APHA, 2012).

\section{Data analysis}

The Shannon-Wiener, Simpson, Pileou's evenness and alpha $(\alpha)$ biological diversity indices were calculated in terms of abundance using PAST software (Hammer et al., 2001; Hammer and Ryan, 2008). A principal component analysis (PCA) based on a correlation matrix among samples was used to analyze the physicochemical parameters. Canonical correspondence analysis (CCA) was also used to describe community trends in macroinvertebrate data and to identify physicochemical variables that best explained species distribution patterns at study sites. PCA and CCA were performed using RcmdrPlugin.FactorMineR and vegan packages, respectively in $\mathrm{R}$ software (version 3.5.1). One-way analysis of variance (ANOVA) test was used to test the significance of physicochemical factors on macroinvertebrate abundance and FFGs differences among the sixteen wetland sites. The non-parametric Kruskal-Wallis test was used if normality was not achieved after transformation (Zar, 1984). ANOVA and Kruskal-Wallis tests were computed using Rcmdr package in R software. Canonical correspondence analysis was used to select linear combinations of physicochemical variables that account for most of the variation in macroinvertebrate distributions (Niba and Sakwe, 2018).

Table 1. Sixteen sampling site coordinates

\begin{tabular}{|c|c|c|}
\hline Site & Latitude & Longitude \\
\hline 1 & N480.'02" & E134'32'39" \\
\hline 2 & N48 $04^{\prime} 00^{\prime \prime}$ & $\mathrm{E} 134^{\circ} 32^{\prime} 42^{\prime \prime}$ \\
\hline 3 & $\mathrm{~N} 48^{\circ} 03^{\prime} 58^{\prime \prime}$ & E13432'49" \\
\hline 4 & N48 $04^{\prime} 02^{\prime \prime}$ & $\mathrm{E} 134^{\circ} 33^{\prime} 10^{\prime \prime}$ \\
\hline 5 & N48 $04^{\prime} 12^{\prime \prime}$ & 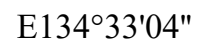 \\
\hline 6 & $\mathrm{~N} 48^{\circ} 04^{\prime} 07^{\prime \prime}$ & $\mathrm{E} 134^{\circ} 33^{\prime} 00^{\prime \prime}$ \\
\hline 7 & N4809'55" & 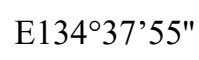 \\
\hline 8 & $\mathrm{~N} 48^{\circ} 10^{\prime} 58^{\prime \prime}$ & $\mathrm{E} 134^{\circ} 39^{\prime} 01^{\prime \prime}$ \\
\hline 9 & $\mathrm{~N} 48^{\circ} 11^{\prime} 40^{\prime \prime}$ & 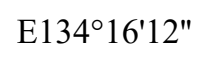 \\
\hline 10 & N4810'13" & 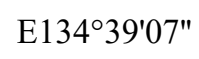 \\
\hline 11 & N4759'52" & E1343ㅇ'14" \\
\hline 12 & $\mathrm{~N} 47^{\circ} 55^{\prime} 00^{\prime \prime}$ & $\mathrm{E} 134^{\circ} 27^{\prime} 57^{\prime \prime}$ \\
\hline 13 & 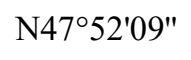 & E13439'19" \\
\hline 14 & $\mathrm{~N} 47^{\circ} 35^{\prime} 45^{\prime \prime}$ & $\mathrm{E} 134^{\circ} 36^{\prime} 00^{\prime \prime}$ \\
\hline 15 & N47º31'57" & 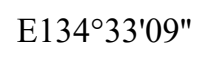 \\
\hline 16 & N48 $18^{\circ} 46^{\prime \prime}$ & $\mathrm{E} 134^{\circ} 06^{\prime} 00^{\prime \prime}$ \\
\hline
\end{tabular}




\section{Results and discussion}

\section{Benthic macroinvertebrate communities}

A total of 57 benthic macroinvertebrate taxa belonging to 24 families were collected from the sixteen sampling sites. Insects were most caught with 11 families Dytiscidae, Chironomidae, Leptophlebiidae, Belostomatidae, Corixidae, Gerridae, Corduliidae, Gomphidae, Macromiinae, Libellulidae and Phryganeidae. In general, Chironomids were the most diverse and abundant family, which possessed 26 taxa followed by Gomphidae with 4 taxa (Table 2). Among all populations, Cipangopaludina ussuriensis (Viviparidae) was the most abundant species representing up to $18.2 \%$ and occurring at almost each sampling site expect for sites 1, 2, 6 and 13. Leander modestus (Palaemonidae) was dominant on site 7, and Cipangopaludina ussuriensis on sites 16 and 10, respectively. Total taxon richness was higher in spring and at site 16. The Shannon-Wiener diversity index was higher at sites 8 and 14, respectively (Fig. 2). We observed that these sites were dominated abundantly by aquatic Poaceae vegetation. Aquatic vegetation plays an important role in structuring macroinvertebrate populations via the provision of living space (Angradi et al., 2001; Sipkay et al., 2005; Ali et al., 2007; Valinoti et al., 2011; Gleason et al., 2018) or the selecting species traits related to population dynamics and feeding habits (Céréghino et al., 2008).

Table 2. Diversity broad outline and relative abundance of benthic macroinvertebrates collected in Sanjiang plain wetland

\begin{tabular}{|c|c|c|c|}
\hline Order & Family & Species & $(\%)$ \\
\hline Arhynchobdellida & Haemopidae & Whitmania laevis & 0.3 \\
\hline Coleoptera & Dytiscidae & Cybister cimbatus & 0.3 \\
\hline Decapoda & Palaemonidae & Leander modestus & 12.1 \\
\hline \multirow{20}{*}{ Diptera } & \multirow{20}{*}{ Chironomidae } & Chinonomus lugubris & 1.3 \\
\hline & & C. riparius & 1 \\
\hline & & C. salinarius & 2.5 \\
\hline & & C. anthracinus & 0.2 \\
\hline & & C. circumdatus & 0.3 \\
\hline & & C. flaviplumus & 0.5 \\
\hline & & C. kiiensis & 0.3 \\
\hline & & C. pallidivittatus & 0.2 \\
\hline & & C. plumosus & 2.5 \\
\hline & & Cricotopus anulator & 0.2 \\
\hline & & C. trifasciatus & 4.1 \\
\hline & & Cryptochironomus defectus & 0.2 \\
\hline & & Dicrotendipes tritomus & 0.3 \\
\hline & & D. nervosus & 0.3 \\
\hline & & Einfeldia dissident & 1.8 \\
\hline & & Glyptotendipes cauliginellus & 1.3 \\
\hline & & G. pauens & 2.3 \\
\hline & & G. tokunagaai & 1.6 \\
\hline & & Orthocladius roussellae soponis & 0.2 \\
\hline & & Parachironomus arcuatus & 0.2 \\
\hline
\end{tabular}




\begin{tabular}{|c|c|c|c|}
\hline & & Polypedilum nubifer & 0.5 \\
\hline & & P. nubeculosum & 2.5 \\
\hline & & Propsilocerus sp. & 2 \\
\hline & & Stictochironomus maculipennis & 0.5 \\
\hline & & Tanypus formosanus & 0.5 \\
\hline & & Tanytarsus mendex & 3 \\
\hline Ephemeroptera & Leptophlebiidae & Leptophlebia sp. & 0.7 \\
\hline Erpobdelliformes & Erpobdellidae & Erpobdella octoculata & 2 \\
\hline Eulamellibranchia & Sphaeriidae & Sphaerium lacustre & 0.3 \\
\hline \multirow{3}{*}{ Heteroptera } & Belostomatidae & Kirkaldyia deyrollei & 0.7 \\
\hline & Corixidae & Corixa substriata & 0.3 \\
\hline & Gerridae & Ranatra chinensis & 0.5 \\
\hline Littorinimorpha & Bithyniidae & Bithynia fuchsiana & 10 \\
\hline \multirow{2}{*}{ Hygrophila } & Lymnaeidae & Lymnaea stagnalis & 4.3 \\
\hline & Semisulcospiridae & Semisulcospira amurensis & 2.3 \\
\hline \multirow{3}{*}{ Architaenioglossa } & \multirow{3}{*}{ Viviparidae } & Cipangopaludina cathayensys & 0.3 \\
\hline & & C. ussuriensis & 18.2 \\
\hline & & Viviparus chui & 1.1 \\
\hline \multirow{7}{*}{ Odonata } & Corduliidae & Somatochlora sp. & 0.2 \\
\hline & \multirow{4}{*}{ Gomphidae } & Gastrogomphus sp. & 0.3 \\
\hline & & Gomphinae sp. & 0.5 \\
\hline & & Ictinogomphus sp. & 0.2 \\
\hline & & Sinictinogomphus sp. & 0.7 \\
\hline & Macromiinae & Epophthalmia sp. & 0.8 \\
\hline & Libellulidae & Brachythemis sp. & 0.2 \\
\hline Hygrophila & Planorbidae & Gyraulus convexiusculus & 1.8 \\
\hline \multirow{2}{*}{ Rhynchobdellida } & \multirow{2}{*}{ Glossiphoiidace } & Glossiphonia lata & 0.3 \\
\hline & & Parabdella quadrioculata & 1.1 \\
\hline Trichoptera & Phryganeidae & Phryganea sp. & 0.2 \\
\hline \multirow{4}{*}{ Tubificida } & Naididae & Nais simplex & 0.5 \\
\hline & \multirow{3}{*}{ Tubificidae } & Branchiura sowerbyi & 0.2 \\
\hline & & Limnodrilus amblysetus & 1.1 \\
\hline & & Limnodrilus hoffmeisteri & 1 \\
\hline Unionoida & Unionidae & Unio douglasiae & 7.2 \\
\hline
\end{tabular}

According to the ANOVA results, the abundance, Shannon-Wiener, Simpson and Pileou's evenness indices were significantly different $(p=0.0163, p=0.0092$, $p=0.0474, p=0.0222$, respectively) among the sixteen sampling sites. On the other hand, it appeared that there's no significant difference in the total abundance and taxa richness of macroinvertebrate communities caught during spring, summer and autumn seasons ( $p=0.229, p=0.7662$, respectively, Fig. $2 c$ ).

Our results agreed with the findings of Wang et al. (2007); Zhao et al. (2012); Zhang et al. (2014); Rosser and Pearson (2018), who reported that insects represented the most diverse group and Chironomids were the most abundant family. Macroinvertebrate biodiversity is mainly determined by the number of taxa and individuals, and higher 


$$
-3394-
$$

diversity can be detected in complex habitats because of more living space or surface area (Shostell and Williams, 2007).
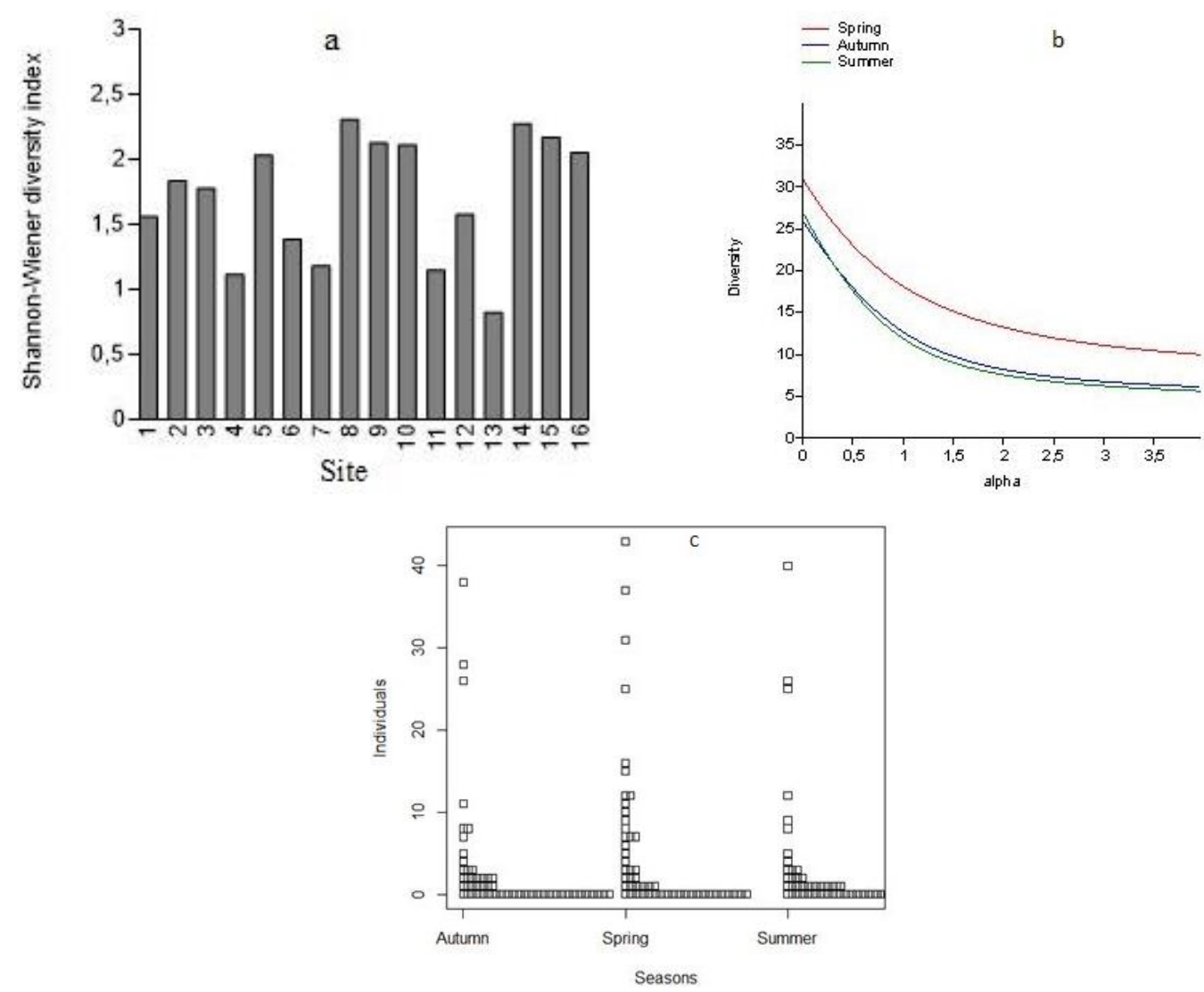

Figure 2. Trends in Shannon-Wiener (a) and alpha (b) diversity indices, and comparison of mean values (c) of the total abundance for each sampling site during autumn, spring and summer seasons. Autumn (26 species, $\left.n_{\text {ind }}=165\right)$, spring (31 species, $\left.n_{\text {ind }}=287\right)$ and summer (27 species, $\left.n_{\text {ind }}=158\right)$

\section{Physicochemical variables at sites}

As summarized in Table 3, some of the measured physicochemical characteristics changed with seasons. Temperature, chlorophyll a, TN, pH and $\mathrm{COD}_{\mathrm{Mn}}$ (KruskalWallis test, $p<0.001$ ) and $\mathrm{NO}_{3}^{-}, \mathrm{TP}, \mathrm{BOD}_{5}$ and turbidity (Kruskal-Wallis test, $p<0.05)$ significantly varied among the sampling sites during these three seasons. While conductivity, chlorine, $\mathrm{NH}_{3}-\mathrm{N}$ and transparency did not vary significantly (Kruskal-Wallis test, $p>0.05$ ) during autumn, spring and summer seasons. Temperature, conductivity, $\mathrm{NO}_{3}{ }^{-}$, transparency, $\mathrm{TP}, \mathrm{COD}_{\mathrm{Mn}}$ and $\mathrm{BOD}_{5}$ increased during the summer, while chlorine, $\mathrm{NH}_{3}-\mathrm{N}$, turbidity and $\mathrm{TN}$ increased during the spring. Moreover, $\mathrm{pH}$ and chlorophyll increased during the autumn. The $\mathrm{pH}$ values indicating the waterbodies of Sanjiang plain tends to be neutral to alkaline. These $\mathrm{pH}$ values were nearly similar to those recorded by Narangarvuu et al. (2014) in the Xindian watershed, Taiwan. According to Grady et al. (2011), at this $\mathrm{pH}$ level, the denitrification process performs well and forms nitrate. 
The sixteen sites were different in terms of water quality (Fig. 3); the first two axes accounted for $62.24 \%$ of the cumulative variance. The sites 1,4 and 6 were characterized by high concentrations of total nitrogen, temperature, chemical oxygen demand, $\mathrm{BOD}_{5}$ and chlorophyll a. While the sites 9, 11, 12, 15 and 16 were characterized by high concentrations of ammonia-nitrogen, conductivity, chlorine, turbidity and total phosphorus. The site 10 was characterized by concentrations of $\mathrm{NO}_{3}{ }^{-}$ and $\mathrm{pH}$. There was also a significant positive correlation between $\mathrm{pH}$ and $\mathrm{NO}_{3}{ }^{-}$.

Table 3. Means and standard deviations of the physicochemical variables at 16 sites

\begin{tabular}{c|c|c|c|c}
\hline Water parameters & Spring & Summer & Autumn & p-value \\
\hline $\mathrm{T}^{\circ} \mathrm{C}$ & $22.19 \pm 1.74$ & $31.36 \pm 2.80$ & $18.93 \pm 1.81$ & $0.0000^{* * *}$ \\
Conductivity $(\mu \mathrm{S} / \mathrm{cm})$ & $118.68 \pm 73.41$ & $119.53 \pm 70.57$ & $70.73 \pm 40.21$ & 0.0847 \\
$\mathrm{pH}$ & $7.19 \pm 0.44$ & $7.42 \pm 0.72$ & $7.78 \pm 0.30$ & $0.0006^{* * *}$ \\
$\mathrm{Cl}^{-}(\mathrm{mg} / \mathrm{l})$ & $4.76 \pm 4.21$ & $2.83 \pm 2.03$ & $2.33 \pm 1.02$ & 0.4304 \\
$\mathrm{NH}_{3}-\mathrm{N}(\mathrm{mg} / \mathrm{l})$ & $0.43 \pm 0.21$ & $0.30 \pm 0.11$ & $0.41 \pm 0.19$ & 0.1122 \\
$\mathrm{NO}_{3}{ }^{-}(\mathrm{mg} / \mathrm{l})$ & $0.63 \pm 0.48$ & $1.18 \pm 1.26$ & $1.14 \pm 0.37$ & $0.0104^{*}$ \\
$\mathrm{Turbidity}(\mathrm{NTU})_{\mathrm{Chlorophyll} \mathrm{a}(\mathrm{mg} / \mathrm{l})}^{82.54 \pm 83.08}$ & $3.60 \pm 3.69$ & $3.65 \pm 4.21$ & $13.19 \pm 9.75$ & $0.0001^{* * *}$ \\
$\mathrm{Transparency}(\mathrm{cm})_{\mathrm{TN}}(\mathrm{mg} / \mathrm{l})$ & $29.43 \pm 19.79$ & $35.40 \pm 28.07$ & $34.00 \pm 24.71$ & 0.6164 \\
$\mathrm{TP}(\mathrm{mg} / \mathrm{l})$ & $8.67 \pm 3.35$ & $4.81 \pm 1.96$ & $3.98 \pm 1.91$ & $0.0001^{* * *}$ \\
$\mathrm{COD}_{\mathrm{Mn}}(\mathrm{mg} / \mathrm{l})$ & $0.20 \pm 0.15$ & $0.39 \pm 0.24$ & $0.33 \pm 0.21$ & $0.0127^{*}$ \\
$\mathrm{BOD}_{5}(\mathrm{mg} / \mathrm{l})$ & $6.47 \pm 8.08$ & $45.15 \pm 36.94$ & $18.27 \pm 14.79$ & $0.0006^{* * *}$ \\
\hline
\end{tabular}

a

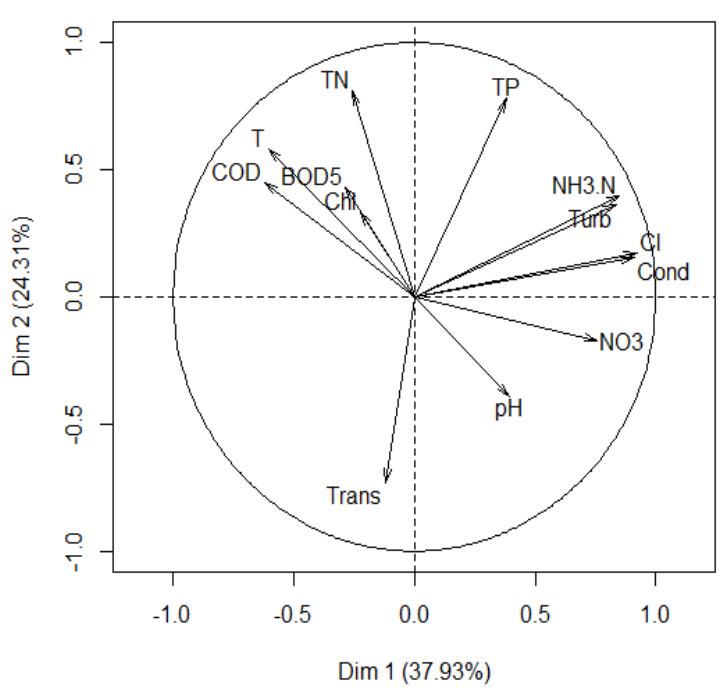

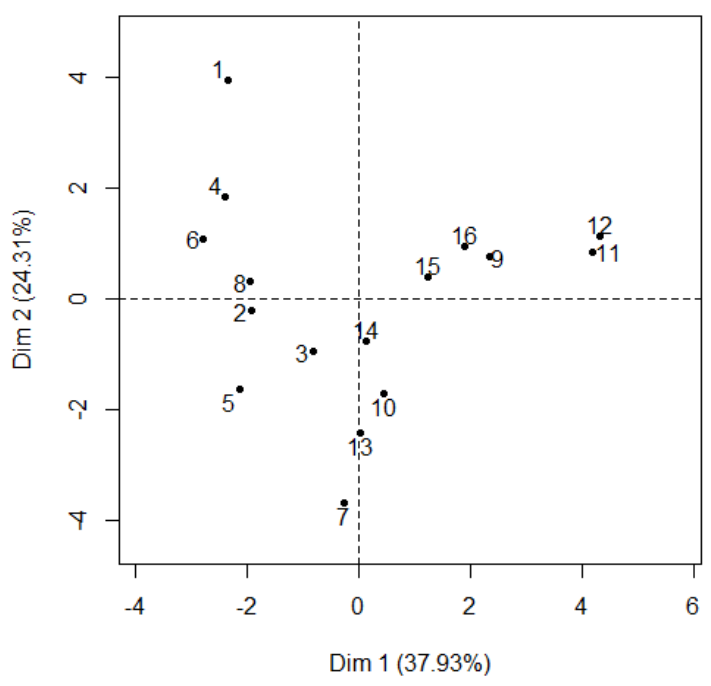

Figure 3. Principal Component Analysis (PCA, $a \& b)$ of the first 2 principal components expressing the relationship sites and physicochemical parameters. $T=$ temperature, Cond $=$ conductivity, Turb = turbidity, $\mathrm{Cl}^{-}=$chlorine, $\mathrm{Chl}=$ chlorophyll $a$, Trans $=$ transparency, $C O D_{M n}=$ chemical oxygen demand, $B O D_{5}=$ biological oxygen demand, $T N=$ total nitrogen, $\mathrm{NH}_{3}-\mathrm{N}=$ ammonia-nitrogen, $\mathrm{NO}_{3}^{-}=$nitrate, $\mathrm{TP}=$ total phosphorus 


\section{Relationships between physicochemical variables and macroinvertebrate FFGs}

The CCA identified 13 physicochemical variables that were significantly correlated with the benthic macroinvertebrate FFGs within the sites (Fig. 4). The first two CCA axes respectively explained 38.27 and $30.58 \%$ of macroinvertebrate FFGs variance, with eigenvalues of 0.33 and 0.27 .

The 57 benthic macroinvertebrate taxa were categorized as follows: 19 predators, 15 gathering-collectors, 7 scrapers, 6 filtering-collectors, 5 omnivores and 5 shredders. According to the percentage contributions of the various macroinvertebrate FFGs (abundance data) within sites, scrapers dominated the benthic communities and accounted for $38.4 \%$ of the total abundance followed by omnivores (17.4\%), filteringcollectors $(15.7 \%)$, predators $(11.1 \%)$, gathering-collectors $(10.0 \%)$ and shredders (7.4\%). Our findings are similar to the results from Zhang et al. (2014), scrapers were the most widely distributed and made up the largest proportion in streams and rivers of a highly developed region, lake Taihu basin, China. Fu et al. (2016) found that predators made up the most contributions to the FFGs (25 taxa) in the Dongjiang River basin, southeast China. Fu et al. (2016) added that shredders and predators mainly included insects, while scrapers were mainly gastropods.

As shown in the Fig. 4, the distribution of scrapers including Bithynia fuchsiana Cipangopaludina cathayensys, Cipangopaludina ussuriensis, Gyraulus convexiusculus, Lymnaea stagnalis, Semisulcospira amurensis and Viviparus chui at sites 8, 9 and 16, which consume algae and associated material were largely influenced by TP and $\mathrm{BOD}_{5}$. Mccormick et al. (2004) reported that TP is an important factor controlling the macroinvertebrate FFG communities. Turbidity, conductivity, ammonia-nitrogen, nitrate, chlorine and $\mathrm{TN}$ were the most important variables to impact the distribution of the filtering-collector FFGs (Glyptotendipes cauliginellus, G. pauens, G. tokunagaai, Sphaerium lacustre, Tanytarsus mendex and Unio douglasiae), which collect FPOM from the water column using a variety of filters at sites 3,11, 12 and 13.

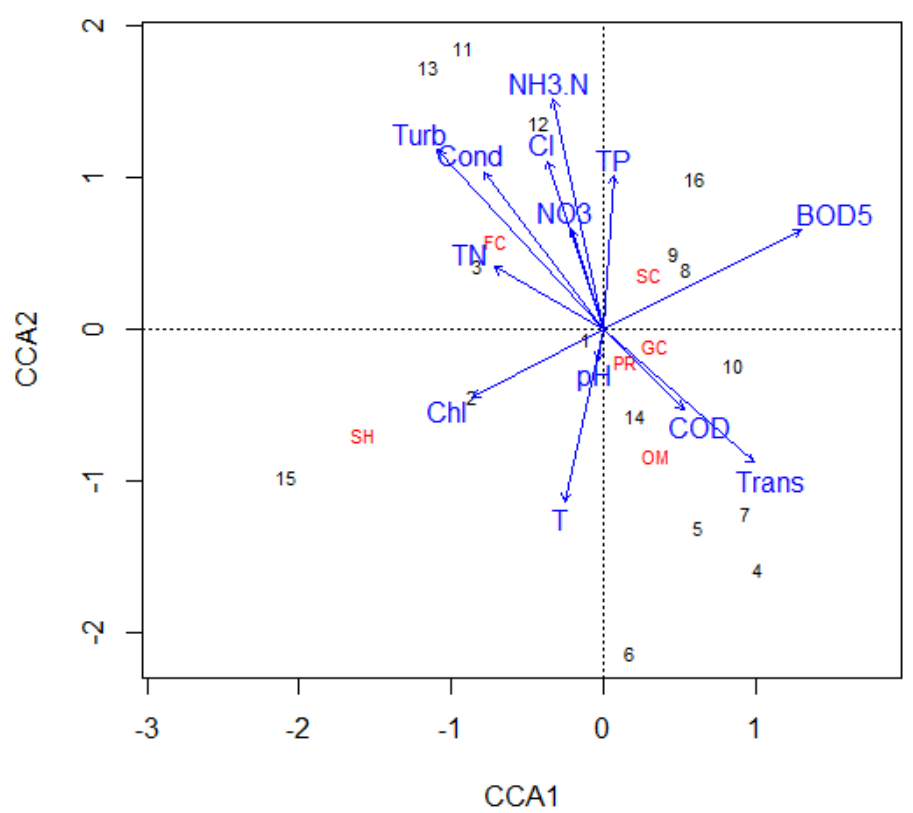

Figure 4. Canonical Correspondence Analysis (CCA) lot relating the macroinvertebrate FFGs to physicochemical factors. $S H=$ shredders, $S C=$ scrapers, $F C=$ filtering-collectors, $G C=$ gathering-collectors, $P R=$ predators, $O M=$ omnivores 
The distribution of gathering-collectors (Branchiura sowerbyi, Chironomus anthracinus, $C$. circumdatus, $C$. flaviplumus, $C$. kiiensis, $C$. pallidivittatus, $C$. plumosus, Dicrotendipes tritomus, D. nervosus, Einfeldia dissident, Leptophlebia sp., Limnodrilus amblysetus, L. hoffmeisteri, Nais simplex and Orthocladius roussellae soponis), predators (Brachythemis sp., Corixa substriata, Cryptochironomus defectus, Cybister cimbatus, Epophthalmia sp., Erpobdella octoculata, Gastrogomphus sp., Glossiphonia lata, Gomphinae sp., Ictinogomphus sp., Kirkaldyia deyrollei, Parabdella quadrioculata, Parachironomus arcuatus, Propsilocerus sp., Ranatra chinensis, Sinictinogomphus sp., Somatochlora sp., Tanypus formosanus and Whitmania laevis), and omnivores (Chinonomus lugubris, $C$. riparius, $C$. salinarius, Leander modestus and Stictochironomus maculipennis) at sites 4, 5, 6, 7, 10 and 14 was strongly associated


tolerant to disturbance and organic pollution, such as Tubifex spp., Limnodrilus spp., Branchiura sp., and Chironomids, which are abundant in polluted rivers. Niba and Sakwe (2018) suggested that benthic macroinvertebrate species populations differently respond to disturbance regimes, and many species have various habitat requirements at each stage of their developmental life cycle (Simaika and Samways, 2011).

The physicochemical factors, such as chlorophyll a, $\mathrm{pH}$ and temperature correlated with the composition of shredders (Cricotopus anulator, C. trifasciatus, Phryganea sp., Polypedilum bubifer and $P$. nubeculosum) which consume leaf litter or other CPOM, were ordinated on the negative part of CCA axis 1 (Fig. 4). Jonsson et al. (2001); Fu et al. (2016) noted that shredders are an important ecological guild in headwater streams, playing a vital role in the process of leaf litter decomposition. They facilitate the release of nutrients into stream ecosystems and provide other invertebrates with food sources in the form of coarse particulate organic matter (CPOM) and fine particulate organic matter (FPOM) (Li and Dudgeon, 2008, 2009; Yule and Gomez, 2009). Nutrient loads could influence macroinvertebrate community structure as a consequence of increased food availability where nutrients stimulate primary production (Gao et al., 2011; Wu et al., 2011; Zhang et al., 2014). Niba and Sakwe (2018) concluded that habitat patch level management along the aquatic ecosystem should aim at preserving sufficient indigenous vegetation categories (riparian, aquatic macrophytes and algae), especially during summer season when habitat requirements are optimal for most growth stages of benthic macroinvertebrate species. The results of Wang and Tan (2017) showed that macroinvertebrate assemblage variations were better explained by water quality factors than land use based on variance partitioning procedures.

\section{Conclusion}

During the three sampling seasons in the wetlands of Sanjiang plain, we recorded 57 taxa of benthic macroinvertebrates belonging to 6 FFGs, including predators, gatheringcollectors, scrapers, filtering-collectors, omnivores and shredders. Insects were the most species-rich group, with 39 taxa and occurred at all sites during spring, summer and autumn. We found higher numbers of macroinvertebrate species and individuals in spring. The results of this study contributed the interesting information about benthic macroinvertebrates FFGs and their relationships with physicochemical parameters in the wetland ecosystems. It was found that predator and scraper FFGs may serve as potential candidates for assessing the health of wetlands. These findings might recommend a need for conservation and management to be targeted in the wetland environments. We 
suggest that further research should be complemented on the composition and structure of macroinvertebrate fauna with an evaluation of density and biomass of FFGs to observe changes from a functional perspective and to obtain an overview on the wetlands of Sanjiang region.

Acknowledgements. This work was supported by a fund from the Ministry of Science and Technology, National Key Research and Development Project (Fund N. 2016YFC0500406). The authors thank the Ministry of Science and Technology for the realization of this work. Our thankful feelings are also addressed to Wenjie Bai from Sanjiang National Nature Reserve, who helped us collect samples during field work.

\section{REFERENCES}

[1] Abel, P. D. (1966): Water Pollution Biology. 2nd Ed. - Taylor \& Francis Ltd, London.

[2] Ali, M. M., Mageed, A. A., Heikal, M. (2007): Importance of aquatic macrophyte for invertebrate diversity in large subtropical reservoir. - Limnologica 37: 155-169.

[3] Allan, J. D. (2004): Landscapes and riverscapes: the influence of land use on stream ecosystems. - Annu. Rev. Ecol. Evol. Syst. 35: 257-284.

[4] American Public Health Association-APHA, American Water Works AssociationAWWA and Water Environment Federation-WEF (2012): Standard Methods for the Examination of Water and Wastewater. 22nd Ed. - APHA, Washington.

[5] Angradi, T. R., Hagan, S. M., Able, K. W. (2001): Vegetation type and the intertidal macroinvertebrate fauna of a brackish marsh: Phragmites vs. Spartina. - Wetlands 21: 7592.

[6] Azrina, M. Z., Yap, C. K., Rahim, I. A., Ismail, A., Tan, S. G. (2006): Anthropogenic impacts on the distribution and biodiversity of benthic macroinvertebrates and water quality of the Langat River, Peninsular Malaysia. - Ecotoxicol. Environ. Saf. 64: 337347.

[7] Bergon, M., Harper, J. L., Townsend, C. R. (1996): Ecology: Individuals, Populations and Communities. - Blackwell Science, Oxford, UK.

[8] Carlson, P. E., Johnson, R. K., Mckie, B. G. (2013): Optimizing stream bioassessment: habitat, season, and the impacts of land use on benthic macroinvertebrates. Hydrobiologia 704: 363-373.

[9] Céréghino, R., Ruggiero, A., Marty, P., Angélibert, S. (2008): Influence of vegetation cover on the biological traits of pond invertebrate communities. - Int J Limnol 44: 267274.

[10] Crisci-Bispo, V. L., Bispo, P. C., Froehlich, C. G. (2007): Ephemeroptera, plecoptera and trichoptera assemblages in two Atlantic Rainforest streams, Southeastern Brazil. Revista Brasileira de Zoologia 24(2): 312-318.

[11] Cummins, K. W. (1974): Structure and function of stream ecosystems. - BioScience 24(11): 631-641.

[12] Cummins, K. W., Wilzbach, M. A., Gates, D. M., Perry, J. B., Taliaferro, W. B. (1989): Shredders and riparian vegetation. - BioScience 39(1): 24-30.

[13] Cummins, K. W., Merritt, R. W., Andrade, P. (2005): The use of invertebrate functional groups to characterize ecosystem attributes in selected streams and rivers in southeast Brazil. - Studies on the Neotropical Fauna and Environment 40: 69-89.

[14] Dentener, F. J., Drevet, J. F., Lamarque, I., Bey, B., Eickhout, A. M., Fiore, D., Hauglustaine, L. W., Horowitz, M., Krol, U. C., Kulshrestha, C., Galy-Lacaux, S., Rast, D., Shindell, D., Stevenson, T., Van Noije, C., Atherton, N., Bell, D., Bergman, T., Butler, J., Cofala, B., Collins, R., Doherty, K., Ellingsen, J., Galloway, M., Gauss, V., Montanaro, J. F., Müller, G., Pitari, J., Rodriguez, M., Sanderson, F., Solmon, S., 
Strahan, M., Schultz, K., Sudo, S., Szopa, W. O. (2006): Nitrogen and sulfur deposition on regional and global scales: a multimodel evaluation. - Glob. Biogeochem. Cycl. 20: $16615-16636$.

[15] Du, B., Zheng, Y., Liu, J., Mao, D. (2018): Threatened plants in China's Sanjiang plain: hotspot distributions and gap analysis. - Sustainability 10: 194.

[16] Duan, X., Wang, Z., Xu, M. (2010): Benthic Macroinvertebrates and Application in the Assessment of Stream Ecology. - Tsinghua University Press, Beijing [in Chinese].

[17] Dudgeon, D. (1999): Tropical Asian Streams: Zoobenthos, Ecology and Conservation. Hong Kong University Press, Hong Kong.

[18] Dudgeon, D., Arthington, A. H., Gessner, M. O., Kawabata, Z. I., Knowler, D. J., Lévêque, C., Naiman, R. J., Prieur-Richard, A. H., Soto, D., Stiassny, M. L. J., Sullivan, C. A. (2006): Freshwater biodiversity: importance, threats, status and conservation challenges. - Biol. Rev. 81: 163-182.

[19] Dunbar, M. J., Warren, M., Extence, C. (2010): Interaction between macroinvertebrates, discharge and physical habitat in upland rivers. - Aquatic Conservation: Marine and Freshwater Ecosystems 20(1): 31-44.

[20] Fu, L., Jiang, Y., Ding, J., Liu, Q., Peng, Q. Z., Kang, M. Y. (2016): Impacts of land use and environmental factors on macroinvertebrate functional feeding groups in the Dongjiang River basin, southeast China. - Journal of Freshwater Ecology 31(1): 2135.

[21] Gage, M. S., Spivak, A., Paradise, C. J. (2004): Effects of land use and disturbance on benthic insects in headwater streams draining small watersheds north of Charlotte, NC. Southeastern Naturalist 3(2): 345-358.

[22] Galloway, J. N., Dentener, F. J., Capone, D. G. (2004): Nitrogen cycles: past, present, and future fruit present and future. - Royal Hortic. Soc. 153-226.

[23] Gao, X., Niu, C. J., Hu, Z. J. (2011): Macrobenthos community structure and its relations with environmental factors in Taihu River basin. - Chin J Appl Ecol 22: 3329-3336.

[24] Gleason, J. E., Bortolotti, Y. J., Rooney, C. R. (2018): Wetland microhabitats support distinct communities of aquatic macroinvertebrates. - Journal of Freshwater Ecology 33(1): 73-82.

[25] Grady, C., Daigger, G., Love, N., Filipe, C. (2011): Biological Wastewater Treatment. IWA, London.

[26] Hammer, O., Ryan, P. (2008): PAST-PAlaeontological Statistics, ver. 1. 77.

[27] Hammer, O., Harper, D., Ryan, P. (2001): PAST: paleontological statistics software package for education and data analysis. - Palaeontol Electronica 4: 1-9.

[28] Hellawell, J. M. (1986): Biological Indicators of Freshwater Pollution and Environmental Management. - Elsevier Applied Science Publisher, London.

[29] Hilsenhoff, W. L. (1988): Rapid field assessment of organic pollution with a family-level biotic index. - J. N. Am. Benthol. Soc. 7: 65-68.

[30] Hynes, H. B. N. (1970): The Ecology of Running Water. - University of Toronto Press, Toronto, Canada.

[31] Jiang, M., Lu, X., Wang, H., Zou, Y., Wu, H. (2011): Transfer and transformation of soil iron and implications for hydrogeomorpholocial changes in Naoli River Catchment, Sanjiang Plain, Northeast China. - Chin. Geogra. Sci. 21(2): 149-158.

[32] Jin, C., Xiao, X., Dong, J., Qin, Y., Wang, Z. (2015): Mapping paddy rice distribution using multi-temporal Landsat imagery in the Sanjiang Plain, northeast China. - Frontiers of Earth Science 10(1): 49-62.

[33] Jonsson, M., Malmqvist, B., Hoffsten, P. O. (2001): Leaf litter breakdown rates in boreal streams: does shredder species richness matter? - Freshw Biol. 46: 161171.

[34] Karr, J. R., Chu, E. W. (1999): Restoring Life in Running Waters: Better Biological Monitoring. - Island Press, Washington, DC

[35] Lenat, D. R. (1993): Using mentum deformities of Chironomus larvae to evaluate the effects of toxicity and organic loading in streams. - J. N. Am. Benthol. Soc. 12(3): 265269. 
[36] Li, A. O. Y., Dudgeon, D. (2008): Food resources of shredders and other benthic macroinvertebrates in relation to shading conditions in tropical Hong Kong streams. Freshwater Biology 53: 2011-2025.

[37] Li, A. O. Y., Dudgeon, D. (2009): Shredders: species richness, abundance, and role in litter breakdown in tropical Hong Kong streams. - J N Am Benthol Soc. 28: 167-180.

[38] Li, X. Z., Liu, R. Y., Liu, J. Y., Liang, X. Q., Chen, G. X. (2007): Fauna Sinica. Invertebrata. Vol. 44. Crustacea: Decapoda: Palaemonoidea. - Science Press, Beijing.

[39] Liu, X. T., Ma, X. H. (2002): Natural Environmental Changes and Ecological Protectionin the Sanjiang Plain. - Science Press, Beijing.

[40] Liu, J. J., Zheng, C. Y., Song, C. C. (2014): Conversion from natural wetlands to paddy field alters the composition of soil bacterial communities in Sanjiang Plain, Northeast China. - Ann. Microbiol. 64: 1395-1403.

[41] Maneechan, W., Prommi, T. O. (2015): Diversity and distribution of aquatic insects in streams of the Mae Klong Watershed, Western Thailand. - Psyche: A Journal of Entomology 1-7. http://dx.doi.org/10.1155/2015/912451.

[42] Masese, F. O., Nzula, K., Kipkembo, J., Gettel, G. M., Irvine, K., McClain, M. E. (2014): Macroinvertebrate functional feeding groups in Kenyan highland streams: evidence for a diverse shredder guild. - Freshwater Science 33(2): 435-450.

[43] Mccormick, P. V., Shuford III, R. B., Rawlik, P. S. (2004): Changes in macroinvertebrate community structure and function along a phosphorus gradient in the Florida Everglades. - Hydrobiologia 529: 113-132.

[44] Merritt, R. W., Cummins, K. W., Berg, M. B. (1996): An Introduction to the Aquatic Insects of North America. Third Ed. - Kendall/Hunt Publishing Company, Dubuque, USA.

[45] Merritt, R. W., Cummins, K. W., Berg, M. B., Novak, J. A., Higgins, M. J., Wessell, K. J., Lessard, J. L. (2002): Development and application of a macroinvertebrate functionalgroup approach to the bioassessment of remnant river oxbows in southwest Florida. Journal of the North American Benthological Society 21: 290-310.

[46] Metcafe, J. I. (1989): Biological water quality assessment of running water based on macroinvertebrate communities: history and present status in Europe. - Environmental Pollution 60: 101-139.

[47] Morse, J., Yang, L., Tian, L. (1994): Aquatic Insects of China Useful for Monitoring Water quality. - Hohai University Press, Nanjing, China.

[48] Morse, J. C., Bae, Y. J., Munkhjargal, G., Sangpradu, N., Tanida, K., Vshivkova, T. S., Wang, B., Yang, L., Yule, C. M. (2007): Freshwater biomonitoring with macroinvertebrates in East Asia. - Front. Ecol. Environ. 5: 33-42.

[49] Narangarvuu, D., Hsu, C. B., Shieh, S. H., Wuc, F. C., Yang, P. S. (2014): Macroinvertebrate assemblage patterns as indicators of water quality in the Xindian watershed, Taiwan. - Journal of Asia-Pacific Entomology 17: 505-513.

[50] Niba, A., Sakwe, S. (2018): Turnover of benthic macroinvertebrates along the Mthatha River, Eastern Cape, South Africa: implications for water quality bio-monitoring using indicator species. - Journal of Freshwater Ecology 33(1): 157-171.

[51] Rosenberg, D. M., Resh, V. H. (1993): Freshwater Biomonitoring and Benthic Macroinvertebrates. - Chapman Hall, New York.

[52] Rosenberg, D. M., Resh, V. H., King, R. S. (2008): Use of Aquatic Insects in Biomonitoring. - In: Merritt, R. W., Cummins, K. W., Berg, M. B. (eds.) An Introduction to the Aquatic Insects of North America. Kendall/Hunt Publishing, Dubuque, Iowa, USA.

[53] Rosser, Z. C., Pearson, R. G. (2018): Hydrology, hydraulics and scale influence macroinvertebrate responses to disturbance in tropical streams. - Journal of Freshwater Ecology 33(1): 1-17.

[54] Safari, R. R., Amundala, S. C., Nabintu, B. N., Shabani, E. I. (2018): Benthic invertebrates of natural ponds of Ruzizi plain, Democratic Republic of the Congo. International Journal of Fisheries and Aquatic Studies 6(2): 381-386. 
[55] Shabani, E. I., Ulyel, J. A.-P., Bolonga, A. B., Wembo, O., Ndjaki, J. N., Tambwe, E. L., Bonyoma, B. F., Toengaho, A. S., Lubunga, P. D., Safari, R. R., Kankonda, A. B. (2016): Preliminary survey on freshwater invertebrates of Mambasa, Democratic Republic of the Congo. - Journal of Animal \&Plant Sciences 29(1): 4567-4574.

[56] Shostell, J. M., Williams, B. S. (2007): Habitat complexity as a determinate of benthic macroinvertebrate community structure in cypress tree reservoirs. - Hydrobiologia 575: 389-399.

[57] Simaika, J. P., Samways, M. J. (2011): Comparative assessment of indices of freshwater habitat conditions using different invertebrate taxon sets. - Ecol Indicators 11: 370-378.

[58] Sipkay, C. S., Hufnagel, L., Gaál, M. (2005): Zoocoenological state of microhabitats and its seasonal dynamics in an aquatic macroinvertebrate assembly (hydrobiological case studies on Lake Balaton, $\mathrm{N}^{\circ}$. 1). - Applied Ecology and Environmental Research 3(2): 107-137.

[59] Smith, R. F., Lamp, W. O. (2008): Comparison of insect communities between adjacent headwater and main-stem streams in urban and rural watersheds. - J. N. Am. Benthol. Soc. 27: 161-175.

[60] Southerland, M. T., Rogers, G. M., Kline, M. J., Morgan, R. P., Boward, D. M., Kazyak, P. F., Klauda, R. J., Stranko, S. A. (2008): Improving biological indicators to better assess the condition of streams. - Ecol. Indic. 7: 751-767.

[61] Sui, X., Zhang, R. T., Yang, L. B. (2017): Differences in the microbial population associated with three wetland types in the Sanjiang Plain, northeast china. - Appl. Ecol. Environ. Res. 15: 79-92.

[62] Tan, K. W., Beh, W. C. (2016): Evaluation of water quality and benthic macrointervebrates fauna relationship using principal component analysis (PCA): a case study of Cameron Highlands, Malaysia. - Environmental Management and Sustainable Development 5(1): 187.

[63] Taufik, M., Setiawan, B. I., Lanen, H. A. J. V. (2015): Modification of a fire drought index for tropical wetland ecosystems by including water table depth. - Agric. For. Meteorol. 203: 1-10.

[64] Thorp, J. H., Covich, A. P. (1991): Ecology and Classification of North American Freshwater Invertebrates. - Academic Press, New York.

[65] Tong, Y. (1996): Annelida, Hirudinae. Fauna Sinica. Natural Science Foundation of China in the Period of the Eighth Five-Year Plan. - Science Press, Beijing (in Chinese).

[66] Valinoti, E., Ho, C. K., Armitage, A. R. (2011): Native and exotic submerged aquatic vegetation provide different nutritional and refuge values for macroinvertebrates. $-\mathrm{J}$ Exp Mar Biol Ecol. 409: 42-47.

[67] Vannote, R. L., Minshall, G. W., Cummins, K. W., Sedell, J. R., Cushing, C. E. (1980): The river continuum concept. - Canadian Journal of Fisheries and Aquatic Sciences 37(1): 130- 137.

[68] Vitousek, P. M., Mooney, H. A., Lubchenco, J., Melillo, J. M. (1997): Human domination of Earth's ecosystems. - Science 277: 494.

[69] Wang, B., Xu, D., Yang, L., Shen, L., Yu, H. (2007): Characteristics of benthic macroinvertebrates communities in relation to environment in upper reaches of the Taihu Lake Watershed in Changzhou Area. - J Ecol Rural Environ 23: 47-51.

[70] Wang, J., Li, M., Zhang, T., Sui, X., Ma, W., Ni, H. W. (2018): Assessment of microbial diversity of Deyeuxia angustifolia wetland through phospholipid fatty acids (PLFA) in Sanjiang plain. - Int. J. Agric. Biol. 20: 1463-1470.

[71] Wang, X., Tan, X. (2017): Macroinvertebrate community in relation to water quality and riparian land use in a substropical mountain stream, China. - Environmental Science and Pollution Research 24: 14682-14689.

[72] Wang, Z., Mao, D., Li, L., Jia, M., Dong, Z., Miao, Z., Ren, C., Song, C. (2015): Quantifying changes in multiple ecosystem services during 1992-2012 in the Sanjiang Plain of China. - Science of the Total Environment 514: 119-130. 
[73] Wu, H., Guan, Q., Lu, X., Batzer, D. P. (2017): Snail (Mollusca: Gastropoda) assemblages as indicators of ecological condition in freshwater wetlands of Northeastern China. - Ecological Indicators 75: 203-209.

[74] Wu, Z., Cai, Y., Chen, Y., Shao, X., Gao, J. (2011): Assemblage structure investigation of macrozoobenthos and water quality bioassessment of the main river systems in Taihu Basin. - J Lake Sci 23: 686-694.

[75] Yang, L., Sui, X., Liu, Y., Wang, J., Wu, Y., Zhang, T., Ni, H. W. (2018): Abundance and diversity of arbuscular mycorrhizal fungi in Calamanrostis angustifolia wetlands of the Sanjiang plain, China. - Int. J. Agric. Biol. 20: 1424-1432.

[76] Yapo, M. L., Sylla, S., Tuo, Y., Boua, C. A., Kouassi, P. (2018): Composition and distribution of aquatic insect community of a non-stocked pond of Banco National Park (Côte d'Ivoire, Western Africa). - JECET, Sec. A 17(2): 247-259.

[77] Yule, C. M., Gomez, L. N. (2009): Leaf litter decomposition in a tropical peat swamp forest in Peninsular Malaysia. - Wetlands Ecol Manage. 17: 231-241.

[78] Zamora-Muñoz, C., Sáinz-Cantero, C. E., Sánchez-Ortega, A., Alba-Tercedor, J. (1995): Are biological indices BMPW' and ASPT' and their significance regarding water quality seasonally dependent? Factors explaining their variations. - Water Res. 29: 285-290.

[79] Zar, J. H. (1984): Biostatistical Analysis. 2nd Ed. - Prentice Hall, Englewood Cliffs, NJ.

[80] Zhang, J., Ma, K., Fu, B. (2009a): Wetland loss under the impact of agricultural development in the Sanjiang Plain, NE China. - Environmental Monitoring and Assessment 166(1-4): 139-148.

[81] Zhang, S., Na, X., Kong, B., Wang, Z., Jiang, H., Yu, H., Zhao, Z., Li, X., Liu, C., Dale, P. (2009): Identifying wetland change in China's Sanjiang plain using remote sensing. Wetlands 29(1): 302-313.

[82] Zhang, Y., Liu, L., Cheng, L., Cai, Y., Yin, H., Gao, J., Gao, Y. (2014): Macroinvertebrate assemblages in streams and rivers of a highly developed region (Lake Taihu Basin, China). - Aquatic Biology 23: 15-28.

[83] Zhao, W., Wang, H., Close, P. G. (2012): Macroinvertebrates in the bed sediment of the Yellow River. - International Journal of Sediment Research 26(3): 255-268.

[84] Zheng, C., Wang, H. G., Liu, J., Song, C., Gao, H., Liu, X. (2013): Characterization of the major capsid genes (g23) of t4-type bacteriophages in the wetlands of northeast china. - Microbiol. Ecol. 65: 616-625.

[85] Zhou, Z., Liu, T. (2005): The current status, threats and protection way of Sanjiang Plain wetland, Northeast China. - Joumal of Forestry Research 16(2): 148-152. 